\title{
The tribal partners of empire in Arabia: the Ottomans and the Rashidis of Najd, 1880-1918
}

\author{
M. Talha Çiçek
}

\begin{abstract}
This article is about an aspect of the Ottoman-Rashidi partnership in the late Ottoman Empire that deeply influenced the order of things in Arabia and resulted in both the Ottomans and the Rashidis becoming more significant actors in regional politics. The main argument is that this partnership made a great contribution to the visibly increasing Ottoman influence in Najd (i.e., central Arabia) and the Persian Gulf in the late nineteenth and early twentieth centuries. At the same time, the Rashidi family's alliance with the Ottoman Empire paved the way for their emergence as a regional power. Since scholarship on the late nineteenth-and early twentieth-century history of Najd and the Arab lands has tended to neglect the importance of this collaboration, the article sets out to analyze it from its inception until its end, drawing on documents from Ottoman, British, German, and Austrian archives.
\end{abstract}

Keywords: The Rashidis; Najd; Arabia; Ottoman rule in the Arab lands; Ottoman imperialism; Arab Bedouins; Wabhabism; the Saudis; the Persian Gulf; Mubarak al-Sabab; World War I in Arabia

During the last quarter of the nineteenth century, the world of empires underwent significant transformations, which affected the situation in central Arabia, or Najd, as well as in the wider Ottoman Middle East. The involvement of the newest additions to the league of empires-especially Germany

M. Talha Çiçek, Department of History, İstanbul Medeniyet University, 34000, Kadıköy, İstanbul, Turkey, talha.cicek@medeniyet.edu.tr, talhacicek@gmail.com.

Author's Note: The author is greatly indebted to the three reviewers of New Perspectives on Turkey for their constructive comments and criticisms, and to Michael D. Sheridan for his careful editing. He is also very grateful to the British Academy and the Royal Society for their generous support within the Newton Fellowship scheme, to the editors of New Perspectives on Turkey, and to Selen Erdoğan and Cemre Baytok for their help during the publication of this article.

This study is supported by Istanbul Medeniyet University's Scientific Research Commission 
and Russia and their eastward expansion - brought about significant changes in the field of interimperial competition. Over the course of time, Britain, by then a naval superpower, felt its position in India to be increasingly under threat and so tried to secure its own access to it. To this end, it brought the Suez Canal under its control, occupied Egypt, and strengthened its position in the Persian Gulf by creating a partnership with the sheikh of Bahrain. All of this resulted in a breakdown in Ottoman-British relations. The Ottoman-British rivalry began in the early 1880s and fundamentally transformed the former's politics: the Ottomans developed close relations with Germany and took measures against British influence in Ottoman territory.

As a result of such fears, the Ottoman government was inclined to establish tighter control over the region's relatively independent Bedouin in the Arabian deserts. As an alliance between the Saudis or Rashidis-the two greatest tribal dynasties in central Arabia- and the British would put the Ottomans in a very difficult position in Syria, Hijaz, the Persian Gulf, and even Iraq, the Ottoman rulers decided to focus their efforts on increasing their influence in Najd. Just as they had done in Transjordan and al-Hasa, ${ }^{1}$ their initial plan was to expand their administrative apparatus into central Najd, thereby extending Ottoman governance into the area.

In the nineteenth century, the Najd region comprised four subregions. Jabal Shammar, in the northwest, was the Rashidis' core region, and was located on the pilgrimage road between Medina and Iraq. ${ }^{2}$ This route was used especially by Shiite pilgrims, who visited Karbala before proceeding to the Hijaz; al-Hasa, which was captured by Midhat Pasha in 1871, constituted its boundary on the gulf side. Being situated along the gulfs western shore, the area had strategic importance for the control of naval traffic there, with al-Qasim serving as a buffer zone between Medina and Riyadh; i.e., between the Ottomans and the Saudis. Therefore, possession and control of the area was crucial for the Ottomans to secure the empire's control over the holy places. ${ }^{3}$ Riyadh and its vicinity were especially valuable due to the fact that this was the core region for the Saudis, who posed a potential threat to Ottoman rule in the surrounding regions.

1 For a study of the expansion of Ottoman sovereignty into Transjordan, see Eugene L. Rogan, Frontiers of the State in the Late Ottoman Empire: Transjordan, 1850-1921 (Cambridge: Cambridge University Press, 1999). On coastal Najd, see Frederick F. Anscombe, The Ottoman Gulf: The Creation of Kuwait, Saudi Arabia and Qatar (New York: Columbia University Press, 1997).

2 For studies on Ottoman modernization in Iraq, see Ebubekir Ceylan, The Ottoman Origins of Modern Iraq: Political Reform, Modernization and Development in the Nineteenth Century Middle East (London: I.B. Tauris, 2011); Gökhan Çetinsaya, The Ottoman Administration of Iraq, 1890-1908 (London: Routledge, 2006).

3 For a recent dissertation on Qasim that analyzes the region's ruling elites, merchant classes, and trade networks, see Peter C. Valenti, "State-Building in Central Arabia: Empires and Regional Actors at the Crossroads of al-Qasim," (Ph.D. dissertation, New York University, 2015). 
Following two failed attempts, which will be described below, to establish direct control over this strategic region, the Ottoman government established a partnership with the Rashidis, providing them with generous support and helping them against any local threats to their rule before finally withdrawing from the region in 1918. For their part, the Rashidis did not challenge the authority of the caliph and abstained from developing relations with other powers so as not to invite Ottoman suspicions.

This article will look at the rise of the Rashidis together with their suzerain's attempts to become more influential in Najd by focusing on the mutual dependence between the two parties. This approach is adopted because Ottoman strategies for increasing their influence in the region cannot be understood without also considering the interests, ideals, and values of their Rashidi partners, who themselves influenced the implementation not only the imperial center's plans, but also, and especially, the final outcome.

Only a few studies have dealt with either relations between the Ottoman government and Arab tribal leaders in general or the history of the late Ottoman Empire in Najd in particular. Since Najd was never integrated into the central administration, some of these studies have presented the region's dynasties as nearly independent actors. For example, Madawi al-Rasheed's book on the rise and fall of the Rashidis, which does not draw on Ottoman state documents, minimizes the empire's role in Najdi affairs and in fact completely disregards the Ottoman contribution to the rise and maintenance of Rashidi power. ${ }^{4}$ On the other side of the coin, studies that do make use of Ottoman sources sometimes exaggerate the role of the imperial authorities. For instance, Zekeriya Kurşun's study on the Saudis, which is dedicated to proving the strength of the center, rather naively overestimates Ottoman power. ${ }^{5}$ Frederick Anscombe's book on the creation of Kuwait and Qatar and the rise of the Saudis also touches upon this issue. Influenced by theories of modernization, Anscombe evaluates Ottoman policies according to what they wanted to do, rather than what they actually did. In his view, Ottoman policies in the Persian Gulf and Arabia were ultimately unsuccessful because they failed to establish a proper, centralized administration there. However, he pays no attention to the nearly half century (1871-1918) of success in terms of maintaining peace and preventing challenges to their supremacy, a success

4 Madawi al-Rasheed, Politics in an Arabian Oasis: The Rashidis of the Saudi Arabia (London: I.B. Tauris, 1991). Although al-Rasheed neglects the Ottoman role in the rise of the Rashidis, oddly, she still attributes their decline to their allegiance with the Ottomans; see Madawi al-Rasheed, "Durable and Non-Durable Dynasties: The Rashidis and Sa'udis in Central Arabia," British Journal of Middle Eastern Studies 19, no. 2 (1992): 144-158.

5 Zekeriya Kurşun, Necid ve Ahsa'da Osmanlı Hâkimiyeti: Vehhabi Hareketi ve Suudi Devleti'nin Ortaya Çıkışı (Ankara: Türk Tarih Kurumu Yayınları, 1998). 
achieved through negotiation and cooperation with Bedouin forces. Others have argued for the existence of a colonial politics [müstemleke siyaseti] over Najd, claiming that the Ottoman authorities were fully aware of the difficulty of administering the people of this region in the same manner as those in other parts of the empire. Yet it is somewhat ironic to argue for the existence of a colonial attitude in a region where the policies of both the empire and of local actors were shaped on a basis of mutual dependence, with the latter being as decisive as, and often even more decisive than, the former. As such, the most suitable way to describe the Ottomans' relations with the Rashidis is as a partnership within the framework of which both sides were mutually dependent on each other on an equal basis. ${ }^{6}$

The first section of this article deals with attempts made by two Tanzimat statesmen, Midhat Pasha and Abdullatif Subhi Pasha, to establish direct administration over Najd in the early 1870s. Next, it examines the creation of the Ottoman-Rashidi partnership and the Rashidis' subsequent expansion in Arabia. Following this, the article discusses the Rashidis' decline, which was brought about by an alliance of local Bedouin leaders from the Persian Gulf, Najd, and Iraq. Finally, it looks at how the Ottoman-Rashidi partnership came to be reconstituted following the 1902 reemergence of the Saudis and within the context of World War I.

\section{Two governors, two regional perspectives: attempts to integrate central Najd into the Ottoman heartland}

In early 1870, the Ottoman government made two notable attempts to integrate Najd into the Ottoman administration. However, these were not initiated through a decision by the central government, but by two prominent statesmen of the Tanzimat era: Midhat Pasha, the governor general of Baghdad, and Abdullatif Subhi Pasha, the governor of Syria, who persuaded the central government of the necessity to expand Ottoman rule in the region. This stemmed from their respective regional concerns, and thus the perspectives of the two governors were rather different from one another. As will be detailed below, while Midhat's plan was conceived so as to secure Ottoman power in Iraq and the Persian Gulf, Abdullatif Subhi was concerned with maintaining order in Syrian lands and along the pilgrimage route to the Hijaz.

An internecine conflict within the Saudi dynasty presented Midhat Pasha with a golden opportunity to penetrate into the region. In 1871,

6 The chief chamberlain of Sultan Abdulhamid II, Tahsin Pasha, voices this argument in his memoirs, which were written some thirty years later; see Tahsin Pasha, Yıldız Hatıraları, ed. Ahmet Zeki Izgöer (İstanbul: İz Yayıncılık, 2015), 232-234. For a study on Yemen based on this assumption, see Thomas Kühn, Empire, Islam, and Politics of Difference (Leiden: Brill, 2011). 
Amir Abdullah al-Faisal, the progenitor of the Saudi dynasty and the kaimakam (kaza district governor) of Najd, invited Ottoman forces to provide leverage in his struggle against his brother Amir Saud al-Faisal: the former had been appointed kaimakam directly by the sultan, but his post had supposedly been usurped by the latter in the 1860s. Midhat Pasha used the restoration of Abdullah's post as a pretext for a military intervention into Najd meant to put the region under direct Ottoman control. In the operation, ${ }^{7}$ Ottoman troops took control of al-Hasa and, within a few years, the area had been more or less incorporated into the Ottoman administrative system as the subprovince of Najd, remaining as such until Abd al-Aziz ibn Saud reconquered it in 1913. According to his initial plan, Midhat Pasha intended to control the tribes of central Najd by drawing kaimakams from within the Saudi family. But in 1872, Abdullah al-Faisal's independent actions and reluctance to cooperate with the Ottomans led Midhat Pasha to change tack: now setting his sights on eliminating the Saudi dynasty entirely, he appointed a non-Saudi Ottoman bureaucrat as kaimakam, stationed in al-Hasa, and worked to control the tribes through his agency. He informed the sheikhs at Unaizah and Buraidah, the amir of Jabal Shammar, and 24 other Najdi Bedouin chiefs that Abdullah al-Faisal was no longer their ruler and that they should rule their own regions until such time as he sent another kaimakam. He even prepared a plan of action for the army that would have seen the Ottomans advance into Riyadh and take control of central Najd outright. ${ }^{8}$ Ultimately, however, Midhat was compelled by the central government to abandon the idea of military conquest due to the financial costs it would entail as well as the envisioned expedition's distance from the imperial heartland.

At about the same time, in 1872, another ambitious Tanzimat statesman, Abdullatif Subhi Pasha, was making a similar attempt to pacify another tribal dynasty of Najd, the Rashidis, and penetrate into that region. Much as with Midhat Pasha's expedition, Abdullatif Subhi was invited into the Jawf region by the residents, who wished to be saved from the "atrocities" of Amir Muhammad ibn Rashid, the newly emerging independent power in the city of Ha'il. ${ }^{9}$ For this, Abdullatif Subhi prepared a two-stage plan. First, he would establish a kaimakamate (kaza district) in Jawf in northern Najd, which had already been captured by Hiza ibn Shalaan, chief of the Ruwala tribe, on behalf of the government and with the encouragement of the governor of Damascus. Following this, Ottoman troops would be able to move

7 For the details of the expedition, see Anscombe, The Ottoman Gulf, chapters 2 and 3.

8 From Midhat Pasha to the grand vizierate, December 22, 1287 [January 4, 1872], quoted in Yusuf Halaçoğlu, "Midhat Paşa'nın Necid ve Havalisi ile İlgili Birkaç Lâyihası", Tarih Enstitüsü Dergisi 3 (1972), 155.

9 ŞD 2270/19, September 23, 1288 [October 5, 1872]. 
southeast into central Najd. If Ibn Rashid resisted the establishment of Ottoman control in Jawf, the sheikhs of the Seba and Ruwala, branches of the Anizah tribal confederation and rivals of the Rashidis, would stand ready to assist. The reason Subhi wanted to establish a kaimakamate in Jawf was to be able to settle and control the Bedouin tribes there. He planned to annex the villages of the rich district of Khaybar near Medina to Jawf and to post Ibn Shalaan's brother Sattam there as kaimakam, since it was thought that he would act in harmony with the Ottoman administration. In this way, the administration of Jawf would be strengthened both financially and politically. With Jawf thus under control, there would be great economic and political benefits, the pilgrimage route from Syria to Medina would be secured, Ibn Rashid would be weakened, and the threat posed to Ottoman order in Syria and Iraq by the mobile Bedouin tribes of the desert would be eliminated. ${ }^{10}$ Ultimately, however, the first stage of this plan failed, and at the recommendation of Abdullatif Subhi's successor, Halet Pasha, and the Protector of Medina, Halid Pasha, ${ }^{11}$ Ottoman administration over Jawf was abolished in 1873, just one year after its establishment. ${ }^{12}$ The region was thus left to Ibn Rashid, ${ }^{13}$ with whom an agreement was made stating that an Ottoman officer with eighty soldiers would remain in the region ${ }^{14}$ and an annual tribute of 70,000 kuruş would be paid to the treasury of Mecca and Medina. According to Süleyman Şefik Söylemezoğlu, however, these tributes were never paid. ${ }^{15}$

Another significant reason behind the Ottoman withdrawal from Jawf can be found when the wider regional context is taken into consideration. The Ottoman administration was consolidated in al-Hasa and Transjordan, and the Saudis were sufficiently weakened. As such, the actual religious and political threat from Najd and the Persian Gulf had been successfully eliminated. Furthermore, in the 1870s, the Rashidis were not powerful enough to be considered threats to Ottoman order in the region, and so it was effectively meaningless for the Ottomans to attempt to maintain the Jawf administration.

10 ID 2270/9, Abdullatif Subhi Pasha to the State Council (Şura-yı Devlet), Damascus, May 12, 1288 [May 25, 1872]; ŞD 2270/16, Abdullatif Subhi Pasha to the State Council, August 26, 1288 [September 8, 1872].

11 Süleyman Şefik Söylemezoğlu, Hicaz Seyahatnamesi (istanbul: İz Yayıncılık, 2012), 78.

12 Later, Ottoman officials and local notables in the region would occasionally advise the central government to reassert its authority in Jawf. The government, however, having learned from Abdullatif Subhi Pasha's experience, did not accept such proposals. For examples of this, see ŞD 260/ 43, August 27, 1291 [September 9, 1875]; Y.PRK.ASK. 80/57, March 8, 1308 [March 21, 1892]; and BEO 78/5797, Rebiülevvel 17, 1310 [October 9, 1892]. Reports sent after 1900 highlighted, again, that the region should be administered by the Ottomans so as not to allow the British to colonize it; see DH.i.UM. E-67/11, April 17, 1329 [April 30, 1913].

13 A.MKT.MHM. 463/30, Receb 14, 1290 [September 8, 1873].

14 al-Rasheed, Politics, 205.

15 Söylemezoğlu, Seyahatname, 78. 
The impact of all these experiences also led the Ottomans to understand the difficulty of using coercive measures to control the Bedouins in Najd and other regions. They were instead compelled to cooperate with the local power-holders, and to that end-and especially considering the increasing influence of the British and their occupation of Egypt-the Ottomans increased their support for the Rashidi dynasty. The goal in doing this was to satisfy all the relevant regional concerns regarding the importance of Najd; namely, the security of Syria, the Hijaz, Iraq, and the Persian Gulf, all of which would be guaranteed through Rashidi domination over central Arabia. This is how the foundations of the Ottoman-Rashidi partnership, which would continue until the end of Ottoman control over Arab lands, were laid.

\section{A partnership in the making: the increase of Ottoman influence in Najd and the rise of the Rashidis}

The Rashidis initially emerged as the leaders of the tribes in Jabal Shammar in the first half of the nineteenth century, following a long series of struggles. The Shammar tribes, who constituted the main Bedouin group supporting the Rashidis in Najd, had opposed the political ambitions of Wahhabism and defended their region against Saudi-Wahhabi expansion in the late eighteenth and early nineteenth centuries, when the latter had invaded parts of Iraq and the Hijaz. After the Egyptian occupation of the Hijaz, the Rashidis cooperated with the Egyptian government to maintain control over Najd. In 1836, encouraged by Egyptian rulers and supported by the Saudis, Abdullah ibn Rashid declared himself ruler of Ha'il in Jabal Shammar, which later became the capital of all the Shammar tribes including the Rashidis. This was in line with Egyptian policy, which aimed at destroying Saudi-Wahhabi hegemony in Najd. ${ }^{16}$

Not only did the Rashidis maintain their supremacy in Jabal Shammar after the restoration of Ottoman rule in Arabia, which followed the withdrawal of Egyptian forces in 1840, but they even extended their authority northwards and southwards. By the early 1840s, Jawf was under Abdullah ibn Rashid's control, and his successors competed with the Unaizah and Buraidah Bedouin of Qasim for sway over this region, which was an important one for any power

16 It is worth mentioning that Abdullah ibn Rashid was supported by the Saudis as well; see al-Rasheed Politics, 43-45. Söylemezoğlu's account also confirms the account in Al-Rasheed's book, while giving much additional information; see Söylemezoğlu, Seyahatname, 191-200. When Rashidi cooperation with the Egyptians and the Shammars' opposition to Wahhabi hegemony in the region are taken into account, the Saudi support for Abdullah seems contradictory. The reason for this support, however, may have been the desire to maintain Saudi ties, albeit loosely, with the Rashidis, due to the fact that they lacked coercive means to dissuade Abdullah from his decision at that time. 
hoping to establish supremacy over Arabia. ${ }^{17}$ During the time of Talal ibn Rashid (r. 1843-1867), some Qasimi tribal leaders unhappy with Saudi rule invited the Rashidis there, thus allowing the latter to extend partial control over that district as well. ${ }^{18}$ It appears that, in spite of the weakness of the Saudis, the Rashidis nominally accepted their superiority until the time of Amir Muhammad ibn Rashid (r. 1872-1897). Similarly, from the amirate of Talal on, the Rashidis began to act in a manner that was appreciated by the Ottoman rulers. They secured the pilgrimage route from Iraq to Mecca and did not neglect to mention the caliph during Friday prayers. Talal, in particular, was very careful to avoid conflict with the Ottomans, and he declared to his people that he was acting on the caliph's behalf and accorded great honor to the Ottoman officials who visited him, on all occasions making it clear to the Ottomans that he was a loyal servant of the caliph. ${ }^{19}$

Although, like many other tribal leaders in Arabia, the Rashidis accepted Ottoman suzerainty, the Ottoman rulers actually did little to increase cooperation until the early 1880 s, at which time Ottoman interest in the Rashidis gradually increased and was finally transformed into a partnership. The British consul in Damascus reported in 1885 that negotiations between the governor of Syria and Muhammad ibn Rashid gave considerable satisfaction to Istanbul. In that year, the sultan's aide-de-camp visited Ibn Rashid, charged with acquiring his friendship, and in the next year the sultan sent a commission to investigate Ibn Rashid's loyalty and guage his influence over the Bedouin in the region. ${ }^{20}$ According to the consul, the reason behind the new Ottoman approach toward "the most powerful leader" in Najd was the disaffection in Yemen, as well as the general interest taken in the Sudan rebellion. ${ }^{21}$

Furthermore, the establishment of a subgovernorate (mutasarriflik) in al-Hasa and the occupation of Egypt by the British beginning in 1882 made the Ottoman government more sensitive to local and global threats to its position in the Persian Gulf and along the northeastern shore of the Red Sea. The Saudis had a strong influence over the tribes in coastal Najd, and as a result they threatened the province's stability whenever they gained a bit of strength. In 1879, for instance, the governor of Basra pointed out the threat the Saudis

17 al-Rasheed, Politics, 150-153.

18 Söylemezoğlu, Seyahatname, 196.

19 Ibid.,196-197.

20 Y.EE. 6/52, "Ba Irade-i Seniyye Cebel-i Şemmer Şeyhi Muhammed b. Reşid Nezdine l'zam Olunan Komisyonun Vezaifine Dair Ta'limatnamedir," undated. Citing British sources, Anscombe claims that the aim of this mission was to obtain permission for the establishment of an Ottoman mosque and school in Ha'il. However, the instructions given to the commission members do not include such information; see Anscombe, The Ottoman Gulf, 68.

21 FO 195/1514, April 30, 1885. 
were posing there, ${ }^{22}$ while in 1880 , Abdullah ibn Saud demanded that the sultan appoint him subgovernor of Najd for the security of Mecca, Medina, and the Arabian peninsula; this was interpreted by the Ottoman rulers as a threat to the empire's presence in al-Hasa. ${ }^{23}$ In 1887, when Muhammad ibn Saud deposed Abdullah al-Faisal, he wrote to many in al-Hasa and Qatif that before long he would rid them of the Ottoman occupation. ${ }^{24}$ Even after Muhammad ibn Rashid had captured Riyadh, Abd al-Rahman bin Faisal remained dangerous for the Ottoman administration of $\mathrm{Najd}^{25}$ It is worth mentioning that all of this actually occurred during some of the Saudi dynasty's weakest moments, so it would not be strictly accurate to claim that the Ottomans benefited from the Rashidi-Saudi conflict in Arabia.

It was during this period as well that British and French officials and travelers who visited Muhammad ibn Rashid were allegedly providing him with military aid. Ottoman reports from 1883 state that Ibn Rashid was visited by British officials disguised as travelers, ${ }^{26}$ while in 1884 the French traveler and scholar Charles Huber was murdered by his guide around Jeddah as he was on his way to Ha'il to pay Ibn Rashid a visit. ${ }^{27}$ Also in 1884 , some seventeen British officials paid him a long visit to donate nine boxes of Martini rifles. ${ }^{28}$ There were also two other foreigners who came to the amir and presented him with considerable quantities of rifles and ammunition. ${ }^{29}$ Another French traveler, Marquis, was planning to go to Ha'il, but had to delay his visit. ${ }^{30}$ Later, in the 1890s, Muhammad ibn Rashid also seemed to incline toward becoming a potential ally of the British, due to talks regarding a project to connect the Red Sea to the Persian Gulf via a railway that would run from Suez through Akaba and thence across Arabia to the gulf. ${ }^{31}$ The Ottoman government, meanwhile, was especially concerned that the British would proclaim a protectorate over Jabal Shammar ${ }^{32}$ and provoke the Rashidis to attack Baghdad. ${ }^{33}$ As such, in order to maintain control in Arabia as well as in Iraq, Syria, and even Yemen, the Ottomans considered it crucial to bring the

22 DH.ŞFR 113/10, Teşrin-i sani 7, 1295 [November 19, 1879].

23 Y.PRK.AZJ 3/85, Shaban 4, 1297 [June 12, 1880].

24 FO 78/4011, December 24, 1887.

25 BEO 7/474, March 8, 1308 [March 21, 1893].

26 Y.PRK.UM 5/100, May 14, 1299 [May 27, 1883].

27 CADN, Constantinople Serie D, Damas, 166PO/D20/13, September 26, 1884.

28 Y.MTV 14/43, March 9, 1300 [March 22, 1884].

29 DH.MKT 1344/91, July 8, 1300 [July 21, 1884]. French consular reports confirm the visit of foreigners to Ibn Rashid; for details, see CADN, Constantinople Serie D, Damas, 166PO/D20/13.

30 CADN, Constantinople Serie D, Damas, 166PO/D20/13, June 19, 1884.

31 For the details of this project, see FO 371/2783, November 2, 1916.

32 Y.MTV 48/82, February 20, 1306 [March 5, 1891]; Y.PRK.SRN 3/28, January 30, 1307 [February 12, 1892].

33 DH.MKT 1345/49, August 9, 1300 [August 22, 1884]. 
Rashidi and Saudi dynasties under their control. Midhat Pasha and Abdullatif Subhi Pasha's experiences had already demonstrated the inefficiency of the methods of the Tanzimat period, and so now the Ottomans were more inclined to favor their earlier approach of controlling the region through an amir. ${ }^{34}$ All of these factors ultimately compelled the imperial authorities to strengthen their local alliances so that the Ottoman government in the Hijaz, Iraq, al-Hasa, and Syria could become immune to threats emanating from Najd.

The Rashidis obtained great advantage from their partnership with the Ottomans. Due to Sultan Abdulhamid II's reliance upon Muhammad ibn Rashid and the latter's promotion of their relationship, the spread of Rashidi power was tolerated-in stark contrast to Ottoman policy toward the Saudi dynasty and to the detriment of the Saudis and other local power-holders. The Ottoman governments in Medina, al-Hasa, Basra, Baghdad, and Syria would be admonished by the central government whenever they intervened militarily in conflicts between the Rashidis and other tribes. ${ }^{35}$ However, when the Rashidis would attack tribes under the government's jurisdiction and tax lands controlled by the empire, Ibn Rashid would be sternly warned to abstain from such actions. ${ }^{36}$ In 1892, for example, Ibn Rashid levied taxes in the kazas of al-Ula and Khaybar, in Medina. ${ }^{37}$ Following complaints from villagers and tribesmen, he was then warned that the region was under the jurisdiction of the Protector of Medina and cautioned not to do this in the future. ${ }^{38}$ Similarly, when in 1895 some tribes annexed to the province of Najd in al-Hasa were plundered by Ibn Rashid, the government reprimanded him and returned the stolen goods. ${ }^{39}$

By securing the friendship of Ottoman representatives in the surrounding region, Muhammad ibn Rashid was able to broaden his tribal networks from Iraq and Syria to the Hijaz. In Basra, the Rashidis allied with the Sadunis and the al-Zafirs of the Muntafiq tribal confederation. ${ }^{40}$ In coastal Najd, Qasim al-Thani, the sheikh of Qatar, also developed close relations with Muhammad ibn Rashid. ${ }^{41}$ In Mosul and Aleppo, the Hamound tribes advised him on trade. ${ }^{42}$ What is more, under Ibn Rashid, the Rashidis were able to increase

34 An unsigned report submitted to Abdulhamid II harshly criticized Midhat Pasha's activities and strongly advised the sultan to return to these earlier methods; see Y.PRK.UM 5/100, May 14, 1299 [May 27, 1883].

35 See, e.g., Y.PRK.ASK 46/62, May 17, 1304 [May 30, 1888].

36 See, e.g., DH.MKT 1672/116, October 29, 1305 [November 10, 1889].

37 BEO 90/6701, September 6, 1308 [September 19, 1892].

38 Y.A.HUS 265/120, Rebiülevvel 19, 1310 [October 11, 1892]; BEO 90/6701.

39 Y.A.HUS 327/43, April 1, 1311 [April 14, 1895].

40 DH.ŞFR 137/54, October 6, 1304 [October 19, 1888]; Y.MTV 48/79, February 17, 1306 [March 2, 1891].

41 Y.MTV 48/79, February 17, 1306 [March 2, 1891].

42 DH.ŞFR 137/23, September 18, 1304 [October 1, 1888]. 
their revenue through the pilgrimage route and trade caravans. ${ }^{43}$ As for the Ottomans, they further cemented Rashidi loyalty by paying considerable salaries and providing grain ${ }^{44}$ to Ibn Rashid and other prominent figures under him, as well as annually sending him a prestigious bil'at (robe of honor). ${ }^{45}$ This latter gift was initially opposed by the Hijazi authorities because it was claimed that for Ibn Rashid to receive such a gift directly from the sultan would make him equal to the amir of Mecca, which would not be fitting; instead, it was explained, Ibn Rashid should be given the bil'at by the amir of Mecca and the governor of the Hijaz, as was the case with other tribal leaders in the region. ${ }^{46}$ In addition to all this, Ottoman control of the tribes in the cities of coastal Najd also deprived the Saudis of their main sources of income, resulting in their expulsion from Riyadh and opening the way for Rashidi entry. ${ }^{47}$ It was in this manner that the Rashidis, most especially under the leadership of Muhammad ibn Rashid, were able to establish their hegemony in Najd between 1887 and 1902.

Developments dating to before Muhammad ibn Rashid's expedition against Riyadh shed light on how the Ottomans supported Rashidi power. In December 1887, Muhammad ibn Saud, the son of the "rebellious" Saud alFaisal, seized and imprisoned his uncle, the amir of Riyadh Abdullah al-Faisal, thereby usurping his position. He then wrote to Muhammad ibn Rashid demanding that Buraidah and Qasim be returned to him. As already mentioned, he also wrote to numerous people in al-Hasa and Qatif, "hinting that he [would] shortly free them from the Turkish occupation." 48 After becoming amir, Muhammad ibn Saud consolidated his power, working to draw back into his orbit those tribes that had fallen away during the time of the previous amir. Through emissaries and through letters, he actively incited the people of al-Hasa to rise up against Ottoman rule, promising them aid in return. ${ }^{49}$ In January 1888, the British consul at Basra reported that Nafiz Pasha, Basra's governor, had incited Muhammad ibn Rashid to invade Riyadh and induced certain Arab tribes in Basra to aid him. ${ }^{50}$ Two weeks later, and with Nafiz's consent and approval, Ibn Rashid summoned his partisans to join him. ${ }^{51}$

43 For a detailed analysis, see al-Rasheed, Politics, chapter 2. Please note, however, that a problem with this chapter is that it completely ignores the imperial aspect.

44 In 1894, the Ottoman government decided to provide Ibn Rashid with 50,000 kıyyes ( 1 kıyye $=1,282$ kilograms) of rice; see DH.MKT 283/23, August 13, 1310 [August 26, 1894]. The amount was doubled the next year; see Y.PRK.ASK 99/93, August 18, 1311 [August 31, 1895].

45 MV 4, June 5, 1301 [June 18, 1886].

46 Y.A.HUS 182/36, June 6, 1301 [June 19, 1885].

47 Anscombe, The Ottoman Gulf, 45.

48 FO 78/4011, December 24, 1887.

49 FO 78/4116, January 4, 1888.

50 FO 78/4116, January $16,1888$.

51 FO 78/4116, January 30, 1888. 
And so it was that, on behalf of the sultan, Muhammad ibn Rashid organized a large expedition against Najd, in which he freed the deposed Abdullah al-Faisal and expelled the sons of Saud al-Faisal from Riyadh. ${ }^{52}$

The establishment of Rashidi hegemony over central Najd made the local and central Ottoman authorities anxious that Ibn Rashid might be harboring intentions at expansion in the future. Influenced by local notables such as the sharif of Mecca and the naqib of Basra, local Ottoman authorities had frequently opposed Ottoman support for Muhammad ibn Rashid for fear that he might become a second Muhammad ibn Saud. ${ }^{53}$ Following his victory over the Saudis, these local bureaucrats seem to have increased the frequency of their complaints in this regard. ${ }^{54}$ The Rashidis' attacks against tribes under government control were also a source of anxiety for central authorities, as well as for the sultan. ${ }^{55}$ As a result, in 1891, Receb Pasha, a trustee of Abdulhamid II, was assigned to investigate Muhammad ibn Rashid's intentions ${ }^{56}$ and decide what measures should be taken to keep him under control. He was instructed to be careful in this, since Muhammad ibn Rashid was a loyal partner of the empire, and he was told that all of his actions must receive approval from the palace. ${ }^{57}$ In the end, the commission reported that the local bureaucrats' worries need not be taken seriously. ${ }^{58}$ Nevertheless, imperial prudence dictated that contact with the Saudis not be abandoned, and so Abd al-Rahman bin Faisal was granted a salary by the Ottoman government and hosted in Kuwait $^{59}$ in order to prevent him from breaking the peace in Najd by inciting

52 Although the sultan did not assign him to this task publicly, Muhammad Ibn Rashid nevertheless still declared that he had occupied Riyadh on behalf of the Ottomans; see DH.MKT 1548/63, September 11, 1304 [September 24, 1888].

53 For some examples from the Hijaz and Baghdad, see Y.PRK.UM 5/100, May 14, 1299 [May 27, 1883]; DH.ŞFR 121/48, March 24, 1300 [April 6, 1884]; and DH.ŞFR 125/153, June 14, 1301 [June 27, 1885]. Using these sources as proof, Kurşun claims that the Ottomans did not support this move, and in fact tried to prevent it; see Kurşun, Necid ve Ahsa, 133-151. However, he does not take into account the fact that the opinions of local bureaucrats were rarely reflected in Ottoman policy; the central government, and the sultan in particular, rarely took them seriously.

54 For some examples from Syria, the Hijaz, Basra, and Baghdad, see DH.ŞFR 125/56, June 18, 1301 [June 21, 1888]; DH.ŞFR 137/15, September 14, 1304 [September 27, 1888]; and DH.MKT 1550/8, September 16, 1304 [September 29, 1888].

55 Y.PRK.ASK 46/62, May 17, 1304 [May 30, 1888]; Y.PRK.TKM 6/47, Şaban 20, 1300 [July 28, 1888]; DH.ŞFR 137/54, October 6, 1304 [October 19, 1888]; DH.MKT 1672/116, October 29, 1305 [November 10, 1889]; and Y.PRK.AZJ 13/55, 1305 [1890].

56 Y.MTV 49/81, March 13, 1307 [March 26, 1891].

57 Y.MTV 48/82, February 20, 1306 [March 5, 1891].

58 Kurşun, Necid ve Ahsa, 146.

59 His salary was 4,000 kuruş per month, and receipt of it was conditional upon his remaining in Kuwait or Zubayr; see BEO 226/1699, June 1, 1309 [June 14, 1893]. He seems not to have been the only person from the Saudi family salaried by the Ottoman government: Turki bin Saud, a cousin living in al-Hasa, also received a salary. The Minister of the Interior stated that, although he was not an important figure in the region, he should receive a stipend because he was liked by the sultan, was 
the tribes against the government, as well as to benefit from his influence against Muhammad ibn Rashid when necessary. ${ }^{60}$ It should be noted thatcontrary to what was claimed by his chief chamberlain, Tahsin Pasha, in his memoirs ${ }^{61}$ - this particular consideration was never actually concretized in the Ottoman policies regarding Najd. Moreover, following the establishment of Saudi supremacy in Qasim and Riyadh, the imperial authorities were compelled to accept his authority.

Muhammad ibn Rashid's astute strategies for keeping the empire on his side were the main factors that ensured the continuation of the Ottoman-Rashidi partnership, and in subsequent years the sultan would dismiss any exaggerated reports by local bureaucrats regarding his supposed inclination to independence. He took advantage of any opportunity to demonstrate his loyalty to the sultan, and studiously avoided any actions that might be misperceived by him. When the Ottoman center grew anxious that he might make an attempt to control the Saudis' former tributaries in coastal Najd and put an end to its administration there, he successfully defused these concerns by not approaching the coast. He also took care to avoid any liaisons that might be misunderstood by the Ottomans. A notable example in this regard was his close relation with the sheikh of Qatar, Qasim al-Thani. Immediately following the invasion of Riyadh, Muhammad ibn Rashid promised to support al-Thani in his dispute with Zaid, the sheikh of Abu Dhabi. Ottoman authorities, however, interpreted this as an attempt to extend Rashidi influence into the old Saudi domains, and as a result, Ibn Rashid entered into no further engagements with al-Thani during the course of his reign. ${ }^{62} \mathrm{He}$ was also careful to abstain from engaging in conflict with Ottoman soldiers and to obey the orders of the imperial authorities. For instance, even after he had established hegemony over Najd, he returned, upon the authorities' request, the goods and animals that his Bedouin forces had plundered from tribes under Ottoman jurisdiction. ${ }^{63}$

from a notable family, and was currently destitute (muhtaç); see DH.MKT 2/51, January 5 , 1309 [January 18, 1894].

60 When Abd al-Rahman bin Faisal applied to the Ottoman government for a salary, the governor of Basra clearly stated that Abd al-Rahman al-Faisal should also receive a salary. If Muhammad Ibn Rashid acted against the government, the latter's influence could be used to neutralize him; see BEO 7/474, March 8, 1308 [March 21, 1893].

61 Tahsin Pasha, Yıldız Hatıraları, 232-234.

62 DH.ŞFR 137/15, September 14, 1304 [September 27, 1888]; DH.ŞFR 137/23, September 18, 1304 [October 1, 1888]; DH.ŞFR 137/46, September 29, 1304 [October 11, 1888]; DH.MKT 1554/14, September 29, 1304 [October 11, 1888]. Similar claims were mentioned in British reports as well; see, for example, FO 78/4116, September 13, 1888.

63 For some examples, see DH.MKT 145/72, September 16, 1309 [September 29, 1893]; Y.A.HUS 327/43, April 1, 1311 [April 14, 1895]; and BEO 627/46973, April 13, 1311 [April 26, 1895]. Ibn Rashid sometimes abstained from attacking the tribes under Ottoman jurisdiction so as not to cause a crisis with the government; see DH.MKT 378/28, May 10, 1311 [May 23, 1896]. 
Furthermore, in contrast to the Saudis, he maintained dialogue with the government and consistently sought to solve problems in the region without resorting to violence.

As a final remark, it should be highlighted once again that Ottoman support was not the sole reason behind the rise of the Rashidis, as, in the final analysis, Muhammad ibn Rashid's skill at keeping local people under his control was just as important a factor. The crucial issue, really, was the empire's reliance upon the Rashidis. Had the Ottoman center assessed Muhammad ibn Rashid as a true threat to its rule in the Arab provinces-as it did with the Saudis-it could well have, and likely would have, lent support to his rival tribes, organized a military expedition, and crippled his power over Najd.

\section{The struggle for supremacy in Arabia: empire, the al-Sabah-Saudi alliance, and the decline of Rashidi power}

Muhammad ibn Rashid's death in 1897 and the accession of Abd al-Aziz to the amirship changed Rashidi policy, and this, in turn, affected the Ottoman partnership. The new amir was ambitious about expanding his territories in Arabia, and to that end, immediately after assuming the amirship, he opened new hostilities with the tribal sheikhs in Basra, Baghdad, coastal Najd, Yemen, and Asir: in April 1899, he attacked the Anizah Bedouins of Deir ez-Zor; ${ }^{64}$ in September 1899, he clashed with Bedouin groups connected to the subprovince of Najd; ${ }^{65}$ and in September 1900, he initiated hostilities against the tribes to the east of Asir (i.e., those of Wadi al-Dawasir and Wadi Najran, on the Yemeni border) ${ }^{66}$ The Ottoman authorities grew anxious regarding his plans to expand his authority over the Persian Gulf. ${ }^{67}$ His authority over Najd and his thirst for power also made other local power-holders concerned for their territories. Eventually, Abd al-Aziz's intention to depose the sheikh of Kuwait, Mubarak al-Sabah, and his disputes with Sadun Pasha of the Muntafiq prompted an alliance between these two sheikhs, led by the former. They were able to organize their alliance without Ottoman intervention because Mubarak al-Sabah had British support. Ultimately, taking advantage of the Najdi tribes' concerns regarding Rashidi rule in Riyadh and Qasim, and with the support of Mubarak, Abd al-Rahman and Abd al-Aziz ibn Saud were able to restore Saudi rule in Najd, with the Rashidis eventually being compelled to withdraw to their capital of Ha'il. ${ }^{68}$

64 DH.TMIK.M 70/2, March 27, 1315 [April 9, 1899].

65 DH.MKT 2253/106, August 13, 1315 [August 26, 1899].

66 DH.TMIK.M 93/50, September 12, 1316 [September 25, 1900].

67 For an Ottoman document regarding this, see DH.ŞFR 231/45, January 13, 1314 [January 26, 1899].

68 For details of these conflicts, see B.J. Slot, Mubarak al-Sabah: Founder of Modern Kuwait, 1896-1915 (London: Arabian Publishing, 2005), 154-168. 
In 1898, using as pretext certain minor incidents occurring between some small tribes, a large-scale war was initiated, pitting the Rashidis on one side against Sadun Pasha and Mubarak al-Sabah on the other. Although there would soon be a limited reconciliation due to pressure from Ottoman authorities, no permanent solution could be found, ${ }^{69}$ and the two sides often accused each other of violating the peace and relaunched hostilities. ${ }^{70}$

The chief obstacle in the way of a settlement was Abd al-Aziz ibn Rashid's desire to see Kuwait in friendly hands, presumably because it was the primary port for Ha'il's trade in the gulf. ${ }^{71}$ To this end, he urged the sultan to extend Ottoman control over Kuwait and agreed to help Ottoman troops establish a subgovernorate there, ${ }^{72}$ declaring his readiness to lend assistance in such an undertaking. ${ }^{73}$ What is more, Abd al-Aziz also allied himself with Mubarak's enemy, Yusuf al-Ibrahim, who was supposedly the wealthiest man in Arabia and who had dedicated himself to deposing Mubarak. He intended to appoint one of his nephews in his stead. ${ }^{74}$ Kuwait was so critically important for Abd al-Aziz that he even considered signing a protectorate convention with the British, in return for which he would guarantee the safe construction of a railway across Arabia, connecting Kuwait with the Red Sea. ${ }^{75}$

Ottoman state documents show that the empire did not intervene directly in this issue, but continued to make great efforts to reconcile the sides up through 1904, when Abd al-Aziz ibn Saud recaptured Qasim and moved closer to the Hijaz. ${ }^{76}$ These efforts at reconciliation on the part of the Ottoman center were motivated primarily by three major concerns. First, local and central authorities were concerned that, in the event of a Rashidi victory, the Rashidi amirate would develop connections with the Persian Gulf and thereby potentially threaten the Ottoman administration in coastal

69 In November 1900, bearing an order from the sultan, the local authorities reconciled Sadun Pasha, Mubarak al-Sabah, and Abd al-Aziz ibn Rashid; see DH.ŞFR 253/97, November 2, 1316 [November 15, 1900]; FO 78/5114, November 17, 1900; and FO 78/5114, November 20, 1900.

70 Shortly after the reconciliation, Mubarak complained to the governor of Basra that his promises regarding the return of Abd al-Aziz ibn Rashid were not true; see FO 78/5173, January 8, 1901. On January 29, 1901, Abd al-Aziz ibn Rashid attacked Mubarak; see DH.ŞFR 255/44, January 16, 1316 [January 29, 1901]. Ibn Rashid generally claimed that Mubarak had provoked the tribes allied with him; see, e.g., DH.ŞFR 276/26, January 24, 1317 [February 6, 1902].

71 FO 78/5174, June 3, 1901.

72 For a telegram by Abd al-Aziz ibn Rashid to the sultan on this issue, see Y.PRK.UM 56/126, Receb 23, 1319 [November 5, 1901].

73 Y.PRK.ASK 178/51, December 18, 1317 [December 31, 1901].

74 Yusuf al-Ibrahim bribed both the Ottoman authorities and Abd al-Aziz ibn Rashid into attacking Kuwait; see FO 78/5174, September 8, 1901. For more on the dispute between him and Mubarak, see Slot, Mubarak al-Sabah, 154-180.

75 FO 78/5174, June 3, 1901; FO 78/5174, May 29, 1901.

76 For some examples of the Ottoman efforts to bring the two sides together, see Y.PRK.ASK 164/2, September 12, 1316 [September 25, 1900] and Y.PRK.ASK 147/93, February 28, 1314 [March 13, 1899]. 
Najd and Basra. ${ }^{77}$ Second, if the Rashidis were defeated, it would mean the collapse of the regional imperial order, which had been built on the OttomanRashidi partnership. ${ }^{78}$ The Ottomans therefore pressed Sadun Pasha and those Anizah tribes hostile to the Rashidis to make peace with Abd al-Aziz ibn Rashid, which led to their withdrawal from the conflict and left Mubarak al-Sabah on his own. ${ }^{79}$ The third and most acute Ottoman concern, however, was the possibility that the British might exploit the tribal dispute in such a way as to be able to intervene in the region, thus threatening the Ottoman position in the Persian Gulf and Arabia. As the Ottoman authorities had it, the British hoped that the hostility between Abd al-Aziz ibn Rashid and Mubarak al-Sabah would create an opportunity for them to intervene in the region. ${ }^{80}$

Despite its concerns, though, the Ottoman authorities did benefit from the dispute between the Rashidis and Mubarak al-Sabah in that they managed, to some extent, to wean the sheikh of Kuwait away from the British, compelling him to accept imperial authority. When Mubarak refused to admit a garrison of Ottoman soldiers and an Ottoman judge into Kuwait and turned to the British, the Ottomans began to plan a military expedition, supported by Abd al-Aziz ibn Rashid. ${ }^{81}$ The Rashidi amir was quite willing to support the expedition, as it would result in the removal of Mubarak and the appointment of an Ottoman bureaucrat in his stead. ${ }^{82}$ The British, however, warned the Ottomans that they would not permit action against the sheikh by either the empire or Ibn Rashid. ${ }^{83}$ As a result, the Ottomans ultimately persuaded Abd al-Aziz to withdraw from Kuwait, partly by compensating him for the military expenditures he had made. ${ }^{84}$ Thus, though the Ottomans were unable to bring Kuwait under their full control, they nonetheless did manage to maintain the status quo.

77 DH.TMIK.M 93/50, August 26, 1316 [September 8, 1900]; DH.TMIK.M 90/42, March 13, 1316 [March 26, 1900]; DH.ŞFR 261/49, June 19, 1317 [July 1, 1901].

78 DH.ŞFR 267/98, July 8, 1317 [July 21, 1901].

79 The Anizah tribes and Sadun Pasha were warned by the Ottoman authorities to abstain from joining Mubarak; see DH.MKT 2540/47, September 22, 1317 [September 5, 1901]. On Sadun Pasha, see Y.PRK. UM 45/102, April 22, 1315 [May 5, 1899] and DH.ŞFR 253/24, October 17, 1316 [October 30, 1900].

80 For an example, see Y.PRK.UM 50/95, June 9, 1316 [June 22, 1900]. Contemporaneous British documents demonstrate that, rather than intervening in these issues, the British tried hard to keep the sheikh of Kuwait quiet and to abstain from a conflict with Abd al-Aziz ibn Rashid; see, e.g., FO 78/ 5114, December 31, 1900.

81 FO 78/5173, May 29, 1901 and June 8, 1901. Ibn Rashid would assist in a planned Ottoman expedition under the command of Ahmed Feyzi Pasha, the commander of the Sixth Army Corps; see DH.ŞFR 266/ 65, September 22, 1317 [October 5, 1901].

82 DH.ŞFR 267/98, July 8, 1317 [July 21, 1901].

83 FO 78/5174, September 30, 1901.

84 Y.PRK.ASK 178/51, December 18, 1317 [December 31, 1901]; FO 78/5174, September 27, 1901. 
The Ottomans had thus withdrawn support for Abd al-Aziz ibn Rashid's plan to annex Kuwait, but he was still able to continue his efforts to topple Mubarak thanks to the financial support he was receiving from Yusuf al-Ibrahim. Given this state of affairs, Mubarak encouraged Abd al-Aziz ibn Saud to attack Riyadh and recapture the surround district. ${ }^{85}$ And so, invited by the Bedouins of Riyadh and with the financial backing of Mubarak, in early 1902 Abd al-Aziz ibn Saud returned to Riyadh and expelled Abd al-Aziz ibn Rashid's men. ${ }^{86}$

Immediately following the restoration of Saudi rule in Riyadh, Abd al-Aziz ibn Saud liaised with Mubarak and began inciting the Bedouin tribes in al-Hasa, which was annexed to the subgovernorate of Najd, against the state. ${ }^{87}$ This alarmed the Ottoman government, with local bureaucrats growing concerned that the restoration of Saudi rule over all of Najd was becoming a distinct possibility. ${ }^{88}$ At first, the government offered no direct military reaction to the Saudi resurgence; instead, they fortified the subprovince using newly stationed soldiers and distributed propaganda pamphlets among the Bedouins. ${ }^{89}$ They also initiated negotiations with Mubarak al-Sabah to push for Abd al-Aziz ibn Saud to return to Kuwait. ${ }^{90}$ In addition, they sought to reach a compromise with Mubarak and Ibn Saud by appointing as the subgovernor of Najd Talib al-Naqib, a local notable who was close to Mubarak. However, while the Ottomans were making such careful maneuvers, Ibn Rashid was not acting in coordination with them: he organized a large expedition against Riyadh, which ultimately ended in failure. ${ }^{91}$ Ottoman documents clearly show that this expedition was undertaken against the sultan's will. Nevertheless, imperial authorities were unable to prevent it because Ibn Rashid's base of operations was too distant from the subprovince. ${ }^{92}$

The return of the Saudis gave new hope to the Najdi Bedouins who were dissatisfied with Rashidi rule. Abd al-Aziz ibn Rashid had been unable to

85 For some Ottoman reports highlighting Mubarak's support for Abd al-Aziz ibn Saud in return for Abd al-Aziz ibn Rashid's taking action against Kuwait, see DH.ŞFR 287/108, June 10, 1318 [June 23, 1902] and DH.MKT 2538/98, September 15, 1317 [September 28, 1901].

The tribes in Riyadh, who were unhappy with Rashidi rule, first invited Abd al-Aziz ibn Saud in 1898, see DH. ŞFR 229/95, November 24, 1314 [December 6, 1898]. He replied to them in September 1900; see DH.TMIK.M 94/33, August 23, 1316 [September 5, 1900]. However, he was not able to recapture Riyadh until 1902; see DH.ŞFR 275/74, January 19, 1317 [February 1, 1902] and Y.MTV 225/120, January 19, 1317 [February 1, 1902].

87 DH.ŞFR 286/79, May 30, 1318 [June 12, 1902].

88 For a report from the Hijaz, see Y.PRK.TKM 45/29, Zilhicce 1319 [March 1902].

89 DH.ŞFR 288/9, June 13, 1318 [June 26, 1902]; DH.ŞFR 289/43, July 19, 1318 [August 1, 1902]; DH.ŞFR 290/7, August 4, 1318 [August 17, 1902].

90 Y.MTV 222/97, October 19, 1317 [November 1, 1902].

91 DH.ŞFR 290/130, August 15, 1318 [August 28, 1902].

92 DH.TMIK.M 130/31, August 20, 1318 [September 2, 1902]. 
establish proper governance in the regions conquered by his predecessor Muhammad. ${ }^{93}$ This, in turn, had led to Rashidi atrocities against the Bedouin groups under their rule, as a means of keeping them under control. As is generally claimed by the existing scholarship, the Najdi tribes did not support Abd al-Aziz ibn Saud primarily owing to the latter's embrace of the Wahhabi ideology. Adding to this, in light of the picture drawn by Ottoman documents it can be concluded that the main reason for the Najdis' dissatisfaction was that they had suffered atrocities at the hands of Abd al-Aziz ibn Rashid, who, unlike his predecessor, acted more like a raider than a political leader. For instance, he frequently raided, and thereby alienated, the Najdi tribes in Qasim and Riyadh, most likely to compensate for his failed expeditions against Kuwait and the Muntafiq tribal confederation. ${ }^{94}$ These expeditions estranged many of Ibn Rashid's allies as well: the British consul in Basra reported that most of his troops did not like him, and that as a result it was certain that Mubarak al-Sabah would ultimately defeat him. ${ }^{95}$ Another report points out that many of Mubarak's own supporters were under Rashidi rule. ${ }^{96}$ In 1898 , Ibn Rashid was even deserted by some branches of the Shammar tribes, the Rashidis' constituent force. ${ }^{97}$ Similarly, in 1902, some 2,000 people of the Shammar fled from Ibn Rashid to take refuge among the Ruwala tribes of Hauran, ${ }^{98}$ while a year earlier, in 1901, some of the tribes being taxed by him-namely, the Walad al-Suleiman and the al-Fuqara-requested government protection against him. ${ }^{99}$

The near constant warfare had seriously damaged the Rashidi economy, based as it was on the pilgrimage, and had caused widespread discontent among their supporters. Between 1901 and 1904, most pilgrims, hoping to avoid the dangers of war, traveled to the Hijaz by sea, which meant a considerable economic loss for the Shammar Bedouins. ${ }^{100}$ As a result, by late 1903, even though the Ottoman authorities were trying to prevent the Najdi tribes from joining him, Abd al-Aziz ibn Saud, with the support of Mubarak al-Sabah and the Bedouins of Riyadh and Qasim, made rapid progress towards Qasim, seized control of large parts of southern and central Najd, and even

93 al-Rasheed, Politics, 154.

94 DH.ŞFR 229/95, November 24, 1314 [December 20, 1898]. For some later documents on how Abd al-Aziz ibn Rashid was not wanted by the Qasimis, see Y.PRK.BŞK 72/45, May 19, 1320 [June 1, 1904] and Y.PRK.ASK 228/33, April 10, 1321 [April 23, 1905].

95 FO 78/5173, November 20, 1900.

96 FO 78/5173, February 19, 1901.

97 Y.PRK.UM 42/62, June 24, 1314 [July 7, 1898].

98 Y.A.HUS 433/140, August 15, 1318 [August 28, 1902].

99 Y.PRK.UM 54/68, June 23, 1317 [July 6, 1901].

100 FO 78/5173, February 19, 1901. An Ottoman report demonstrates that the situation had not changed by 1904; see DH.TMIK.M 166/34, April 10, 1320 [April 23, 1904]. 
threatened Ha'il itself. In the Ottomans' view, this posed a fundamental threat to the Ottoman-Rashidi partnership and, by extension, to Ottoman rule in the neighboring provinces as well.

Greatly concerned by the potential disaster in the Hijaz and Iraq that might ensue should Ibn Rashid be defeated or even ally with them against the Ottomans, ${ }^{101}$ the Ottoman government decided to adopt a proactive policy. In 1903, they began to allow the passage of arms through Basra to Ha'il. ${ }^{102}$ The following year, when this was found to be insufficient, a military expedition to Qasim was planned and implemented, with Abd al-Aziz ibn Rashid being given money, guns, and ammunition to join the expedition ${ }^{103}$ and the objective being to expel the Saudis from Qasim.

Understanding the difficulty of resisting this attack, Abd al-Aziz ibn Saud sought out ways to reconcile with the Ottoman government. In February 1905, following negotiations between Abd al-Rahman bin Faisal-who was not only the governor of Basra, but also Ibn Saud's father-and Mubarak al-Sabah, the Ottoman expeditionary force entered Qasim without having fired a shot. ${ }^{104}$ The Qasimis, weary of Abd al-Aziz ibn Rashid's atrocities, had declared to the Ottoman commander that they would not allow the Ottoman troops so long as Ibn Rashid accompanied them, and so he was ordered not to enter Najd with the expeditionary force. ${ }^{105}$

In order to appease the Qasimis, and with a view to preventing new hostilities between the two dynasties, the Ottoman government set up a buffer province in Qasim. ${ }^{106}$ However, they were unable to set up a sustainable government for several reasons: the great poverty of the region; transportation problems between the new province and Medina and Basra; new disturbances initiated by Abd al-Aziz ibn Rashid; and the machinations of the Saudis. ${ }^{107}$ In the end, all hope of establishing the Ottoman order here was lost when, in April 1906, Ibn Rashid was killed during a battle with Ibn Saud near Qasim. ${ }^{108}$ Shortly thereafter, the Ottoman government was forced to abandon the province to the Saudis. For his part, Ibn Saud, as a gesture

101 DH.MKT 629/55, September 1, 1318 [September 14, 1902].

102 Anscombe, The Ottoman Gulf, 155.

103 DH.TMIK.M 166/34, April 10, 1320 [April 23, 1904].

104 Anscombe, The Ottoman Gulf, 156.

105 Y.PRK.ASK 228/33, April 10, 1321 [April 23, 1905].

106 DH.TMIK.M 193/36, August 11, 1321 [August 24, 1905].

107 For a report on the social and economic conditions, see Y.MTV 278/27, July 20, 1321 [August 2, 1905]. On transportation, see DH.ŞFR 351/69, August 2, 1321 [August 15, 1905] and BEO 2647/198477, August 3, 1321 [August 16, 1905]. For the disturbances, see Y.MTV 280/78, October 26, 1321 [November 8, 1905]. On Saudi machinations, see DH.ŞFR 340785, February 21, 1321 [March 6, 1905]. See also Anscombe, The Ottoman Gulf, 156-157.

108 DH.TMIK.M 221/62, April 13, 1322 [April 26, 1906]. 
of good will, had the 900 Ottoman soldiers remaining in the city sent to Basra. ${ }^{109}$

The death of Abd al-Aziz ibn Rashid initiated an internecine war for the Rashidi amirship, which considerably weakened the dynasty, to the advantage of the Saudis. Abd al-Aziz's son Mitab ibn Rashid emerged victorious and assumed the Rashidi amirship, but in May 1907 he was assassinated together with his brothers, Mizal and Muhammad, by his cousin, Sultan bin Hammud. However, just a year after that, in June 1908, Sultan bin Hammud's brother, Saud bin Hammud, murdered him in turn and took up the Rashidi amirship. Yet he, too, suffered the same fate as his predecessors, being killed by his cousin's maternal uncles. Subsequently, Saud ibn Abd al-Aziz assumed the Rashidi amirship, holding it until 1920. According to local Ottoman officials, the reasons behind this series of assassinations were internal, relating to desires to take up unchallenged leadership of the Rashidis, and neither Ottoman nor British reports made reference to any Saudi conspiracy. ${ }^{110}$ Nonetheless, all these troubles led to a split between the empire and its Rashidi partners. It also signaled the end of the physical Ottoman presence in the region.

While Abd al-Aziz ibn Saud lacked the support of an imperial power such as Great Britain, he nevertheless had skillfully managed to stir up problems in Najd and incite the Bedouin tribes loyal to him into shattering the established order. Later, taking advantage of the crisis that faced the Ottoman Empire during the Balkan Wars of 1912-1913, Saudi forces captured the subprovince of Najd in 1912, allowing the garrison to depart for Bahrain. With this, 42 years of Ottoman administration in al-Hasa came to an end. ${ }^{111}$

\section{World War I, jihad, and the Ottoman-Rashidi partnership}

The outbreak of World War I and the declaration of jihad against the Allied Powers signaled a turning point in the Ottoman policy in Arabia, which also influenced the Ottoman-Rashidi partnership. The Ottoman government's plan was to unite Arabia's tribal dynasties against Great Britain. The Rashidis, who by 1914 had regained some of their former strength, were considered important components of this policy. Although their interests did not always mesh with all the elements of Ottoman tactics, Saud ibn Abd al-Aziz did not oppose the overall Ottoman strategy. Furthermore, as will be detailed below,

109 DH.TMIK.M 235/14, January 12, 1322 [January 25, 1907].

110 al-Rasheed, Politics, 56. For some Ottoman reports and telegraphs on the infighting over the Rashidi amirship, see DH.TMIK.M 2/4 [From the Protector of Medina to the Ministry of the Interior], May 28, 1324 [June 10, 1908] and Y.PRK.MŞ 8/54 [From the Judge of Medina Behcet to Yıldız Palace], April 30, 1323 [May 13, 1907].

111 For more, see Anscombe, The Ottoman Gulf, 159-166 and Kurşun, Necid ve Ahsa, 195-238. 
the Rashidis also made significant contributions to the Ottoman gains on the Medina and Iraqi fronts against the sharif and the British, respectively.

In the early stages of the war, the situation in Arabia was far from conducive to a Rashidi-Saudi alliance against the British. The long-standing historical disputes between the two parties, the most recent chapter of which was detailed above, prevented the implementation of the Ottoman pan-Islamic policy, which required, at the very least, a temporary alliance. The Ottoman aim, then, was to resolve these problems, not only to motivate the Rashidis and Saudis for the jihad, but also to prevent Great Britain from exploiting them to its own advantage. ${ }^{112}$

While Saud ibn Abd al-Aziz ibn Rashid declared his full loyalty to the caliph at the beginning of the war, he also saw the proclamation of jihad as an opportunity to eliminate Abd al-Aziz ibn Saud with the help of the Ottoman Empire. Acting against imperial orders, in early 1915 he advanced into his Saudi territory from the northwest of Riyadh. In the subsequent battle, he won a decisive victory, ${ }^{113}$ with the Saudis losing a considerable number of troops: 1,500 killed and 1,200 wounded. The British representative with Ibn Saud, Captain William Shakespeare, was killed, and three other British officials were captured as well. Moreover, according to a German official in Jerusalem by the name of Prüfer, two sons and three relatives of the Saudi leader were killed as well. ${ }^{114}$ Ibn Rashid wanted to exhibit the heads of the British dead in a square in Damascus, but owing to the treaty between the empire and Ibn Saud, the proposal was rejected by the government. ${ }^{115}$ Following the battle, Ibn Rashid recaptured Qasim ${ }^{116}$ and plundered all the villages there. ${ }^{117}$

British sources claim that Ibn Rashid was encouraged by the Turks. ${ }^{118}$ However, Ottoman records indicate that they took every measure to prevent the confrontation, partly out of concern that their loyal confederates

112 ATASE, Kls. 6, Ds. 32, Fih. 3-8, October 12, 1330 [October 25, 1914]; ATASE, Kls. 6, Ds. 32, Fih. 1-13, September 25, 1330 [October 8, 1914].

113 The governor of Syria, Hulusi Bey, claimed that the reason for the fighting was the rivalry between lbn Subhan, Saud ibn Abd al-Aziz's vizier, and those members of the Rashidi family who had taken refuge with Abd al-Aziz ibn Saud. In the governor's opinion, Saud ibn Abd al-Aziz was too young to rule the dynasty, which was the reason all his administrative responsibilities were being carried out by his vizier. Ibn Subhan had begun to have potential rivals of Saud killed so as to consolidate his authority over the tribe; this was why some members of the family had taken refugee with the Saudis. For further details, see DH.ŞFR 461/55, February 1, 1330 [February 14, 1915]. Similarly, in a letter sent by Saud ibn Abd al-Aziz to Abd al-Aziz ibn Saud, the former blames Ibn Subhan for their conflict; see FO 371/3057, May 7, 1917.

114 PA-AA, Türkei 165, Bd. 37, February 24, 1915.

115 ATASE, Kls. 6, Ds. 32, Fih. 4-20, February 5, 1330 [February 18, 1915].

116 DH.ŞFR 489/29, September 3, 1331 [September 16, 1915].

117 DH.ŞFR August 23, 1331 [September 5, 1915].

118 FO 371/3389, January 17, 1918; FO 371/3047, November 27, 1916; FO 371/2479, December 20, 1915. 
the Rashidis might be defeated, and partly as a consequence of their reconciliatory policy of pan-Islamism. ${ }^{119}$ This was the case despite the fact that Ibn Rashid had produced letters from Ibn Saud proposing cooperation against the Ottoman government. ${ }^{120}$

Soon after the battle, and contrary to the British claims, the Ottoman government called for the restoration of peace between the two tribes. Due to Ibn Rashid's reluctance to join in negotiations, ${ }^{121}$ and at the request of Ibn Saud, the Ottomans organized a mediatory delegation, ${ }^{122}$ which consisted of several prominent Arab figures, including Sharif Faisal and Salih Sharif al-Tunusi. The peace was aimed at securing the allegiance of all Muslim leaders to the caliphate, with special emphasis on Abd al-Aziz ibn Saud inasmuch as he was known for his Wahhabi sentiments, which opposed the legitimacy of an Ottoman caliph. In addition, the Ottomans also sought the two chiefs' support in the Mesopotamian theater of the war. ${ }^{123}$ As a result of pressure from Ottoman authorities, in July $1915 \mathrm{Ibn}$ Rashid consented to peace, with the two chiefs agreeing to return to the status quo ante bellum. ${ }^{124}$

After the restoration of peace, and still anxious about another Ottomanbacked attack by the Rashidis, Abd al-Aziz ibn Saud consciously avoided taking any action against Ottoman interests in Iraq or the Hijaz. While formally recognizing the Ottomans' authority, he nevertheless maintained a balance between the British and Ottoman sides. To the British, he gave the impression that he was battling against Ottoman domination in the region and that he was filled with hatred toward them. ${ }^{125}$ Concurrently, he told Ottoman officials that, even while cooperating with the Ottoman government, he had to take British policy into consideration because they were positioned so close to his own territories. In reality, he was never unconditionally loyal to either side, and ultimately did not choose to fully side with the British until their supremacy in his region had become certain at the end of the war. ${ }^{126}$ On the other

119 ATASE, Kls. 6, Ds. 32, Fih. 3-8, October 12, 1330 [October 25, 1914]; ATASE, Kls. 6, Ds. 32, Fih.4-5, October 13, 1330 [October 26, 1914].

120 PA-AA, Türkei 165, Bd. 37, April 10, 1915.

121 DH.ŞFR 459/43, January 14, 1330 [February 27, 1915].

122 ATASE, Kls. 6, Ds. 32, Fih. 4-38, March 4, 1331 [March 17, 1915].

123 HHStA, PA 38/366, Damascus, June 5, 1915.

124 HHStA, PA 38/366, Damascus, July 21, 1915.

125 FO 371/2140, September 22, 1914. British reports paint Abd al-Aziz ibn Saud as a loyal supporter of Britain and a hater of Ottoman authority. However, when the Ottoman documents are studied, a different picture emerges: it becomes clear that his behavior toward British authorities was part of his attempt to maintain a balance between the two sides. For an example of such documents, see FO 371/3047, November 27, 1916 and ATASE, KIs. 3215, Ds. 42, Fih. 3, December 9, 1917.

126 Even after the fall of Jerusalem, fearing that he might still be defeated by an Ottoman-Rashidi attack, Abd al-Aziz ibn Saud planned to offer the government permission to transport foodstuffs to Damascus via El-Usaym; see ATASE, KIs. 3215, Ds. 42, Fih. 3, December 9, 1917. 
hand, Saud Abd al-Aziz ibn Rashid, unlike Abd al-Aziz ibn Saud, actively aided the Ottomans in the Mesopotamian theater. ${ }^{127}$

At the same time, a new threat was developing for the Ottomans that was potentially graver than these machinations: Sharif Hussein's June 1916 revolt in Mecca threatened Ottoman pan-Islamist policies and caused a reshuffling of the cards in Arabia. In this, Ibn Rashid once again emerged as the empire's most loyal supporter. The Ottoman government's intention was to encourage the Shammar tribe against the sharif, and to this end it provided Saud ibn Abd al-Aziz with artillery ${ }^{128}$ and abundant gold. ${ }^{129}$ However, according to the Austrian consul in Damascus, Ibn Rashid maintained his distance from this project, as he did not want to invite the hostilities of Britain or the region's local powers. What the consul did not consider, however, was the fact that, ever since the advent of its partnership with the Rashidis, the Ottoman government had never been open to the expansion of Rashidi power toward the Red Sea. It thus appears that Enver Pasha, the de facto head of the government, was "cosset[ing] one Amir, while trying to abolish another one."130

With the intensification of the sharifs activities among the tribes around Medina, the Ottoman authorities persuaded Ibn Rashid to resettle in Medain Salih, a station on the Hijaz Railway 350 kilometers north of Medina. There were two aims in moving him there: to frighten and intimidate the disloyal tribes, and to strengthen the sense of allegiance among the loyal tribes. According to the Austrian consul, the Fuqara tribe subsequently abandoned its attacks on the railway, while some branches of the Beni Atije and Beni Sakhr tribes were persuaded to protect it. ${ }^{131}$ Furthermore, Ibn Rashid's relocation made it more difficult for the sharif to move his troops in the area, which helped the Ottomans to defend Medina until February $1919 .{ }^{132}$ At the same time, though, the relocation also created problems between Saud ibn Abd al-Aziz and his tribe, which remained in distant Ha'il. The conjunction of difficulties in provisioning and the problem of distance weakened his authority

127 HHStA, PA 38/369, Damascus, December 11, 1916.

128 TTK, KO Koleksiyonu, 12/143, June 18, 1332 [July 1, 1916]. This document does not, however, make clear exactly why the artillery was sent; it may have been for Saud ibn Abd al-Aziz's self-defense.

129 HHStA, PA 38/369, Damascus, December 11, 1916. Enver Pasha sent Ibn Rashid 20,000 liras in gold, but this document does not explain whether the sum was meant for an operation against the sharif; it is equally possible that it was simply intended to buy his loyalty; see TTK, KO Koleksiyonu 11/149, July 16, 1916 [July 29, 1916].

130 TTK, KO Koleksiyonu 11/132, May 30, 1332 [June 11, 1916]; HHStA, PA 38/369, Damascus, December $11,1916$.

131 HHStA, PA 38/370, Damascus, October 9, 1917; DH.KMS 44-1/20, September 5, 1333 [September 5, 1917].

132 For a recent study on the defense of Medina, see Martin Strohmeier, "Fakhri (Fahrettin) Pasha and the End of the Ottoman Rule in Medina (1916-1919)" Turkish Historical Review 4, no. 2 (2013), 192-223. 
among his people, but he managed to solve these problems using Ottoman gold, the sole solution to tribal dissatisfaction in the region at the time. ${ }^{133}$

In mid-July 1918, Ibn Rashid was forced by the Ottoman government to return to Ha'il. As the Austrian consul had it, the Ottomans had begun to suspect that Saud ibn Abd al-Aziz had entered into alliance with Britain, and as a result they stopped sending him guns and ammunition. Moreover, when Ibn Rashid insisted on remaining in Medain Salih, he became even more suspicious in their eyes. Ottoman officials in Damascus took drastic measures in order to force his return, effectively starving him in Medain Salih by cutting off his supply of foodstuffs. ${ }^{134}$ As to why Ibn Rashid insisted upon staying in Medain Salih in spite of such difficulties, it appears to be because doing so presented him with the opportunity to extend his influence toward the Red Sea, and most particularly into northern Hijaz.

When the Ottomans retreated from the Arab lands in 1918, it also marked the fall of the Rashidis. Initially, the British had considered a Rashidi amirate in Ha'il to be a useful counterweight to Saudi power. The Rashidis, however, maintained their anti-British stance by occupying the Sirhan Valley on the eastern frontier of Palestine, as well as by creating an anti-British axis in Arabia together with the sharif of Mecca, whose dispute with the British stemmed from a violation of promises that the latter had made to him. Eventually, following three British-backed military campaigns, Abd al-Aziz ibn Saud terminated the Rashidi amirate in Ha'il, and just as would later be the case with the Ottoman dynasty, the members of the Rashidi family were sent into exile. ${ }^{135}$

\section{Conclusion}

The Ottoman-Rashidi partnership had a significant impact on the course of events in the late nineteenth and early twentieth-century history of Arabia. The partnership served the interests of both sides. For the Ottomans, the main concern was not lose out in the interimperial competition around Arabia, the Persian Gulf, Iraq, and the Red Sea. Within this context, they intended to eliminate the Saudi dynasty, which posed a threat both ideological and political to the empire's presence in the Arab lands in general and the subprovince of Najd in particular. A related factor was the alarming possibility of a Saudi-British alliance.

133 PA-AA, Türkei 165, Bd. 42, Damascus, January 31, 1918.

134 HHStA, PA 38/371, Damascus, July 16, 1918.

135 For a detailed analysis of the demise of the Rashidi dynasty, see Askar H. al-Enazy, The Creation of Saudi Arabia: Ibn Saud and British Imperial Policy (London: Routledge, 2010): 101-128. 
When the Ottoman rulers realized the limits of their ability to establish direct rule in the region through a proper administrative system, they worked to find a partner in the region. This cleared the way for the rise of the Rashidis, with the ensuing partnership satisfying their political goals as well as those of the Ottomans. With Ottoman support, the Rashidis became the undisputed rulers of central Arabia between the late 1880s and the early 1900s. After 1898 , however, the partnership was weakened, due partly to the long hostilities between Abd al-Aziz ibn Rashid and Mubarak al-Sabah and partly to the return of the Saudis to Najd. In 1906, the Rashidis were forced to retreat to their capital of Ha'il, a development that marked the end of the Ottoman era in Najd. It did not, however, mean the end of the partnership altogether, for the partnership was revived during World War I. With the Ottoman declaration of jihad against the Allied Powers, the Rashidis again became important supporters of Ottoman policies in the region. The end of the war, however, finally spelled the end of the Ottoman-Rashidi relationship.

\title{
References
}

\section{Primary sources}

\author{
Prime Ministry Ottoman Archives \\ (Başbakanlık Osmanlı Arşivi, BOA, İstanbul) \\ A.MKT.MHM (Sadaret Evrak-ı Mektubi Kalemi Mühimme Odası) \\ BEO (Bâb-ı Âlî Evrak Odası) \\ DH.I.UM (Dahiliye Nezareti Idare-i Umumiye) \\ DH.MKT (Dahiliye Nezareti Mektubi Kalemi) \\ DH.ŞFR. (Dahiliye Nezareti Şifre Kalemi) \\ DH.TMIK-M (Dahiliye Nezareti Tesri-i Muamelat ve Islahat Komisyonu Müteferrik) \\ iD (irada Dahiliye). \\ MV (Meclis-i Vükela Mazbatları). \\ ŞD (Şura-yı Devlet Maruzatı) \\ Y.A.HUS (Yıldız Sadaret Hususi Maruzat Evrakı) \\ Y.EE. (Yıldız Esas Evrakı) \\ Y.MTV (Yıldız Mütenevvi Maruzat Evrakı) \\ Y.PRK.ASK (Yıldız Perakende Evrakı Askeri Maruzat) \\ Y.PRK.AZJ (Yıldız Perakende Evrakı Arzuhal ve Jurnaller) \\ Y.PRK.BŞK (Yıldız Perakende Evrakı Mabeyn Başkitabeti) \\ Y.PRK.MŞ (Yıldız Perakende Evrakı Meşahat Dairesi Maruzatı) \\ Y.PRK.SRN (Yıldız Perakende Evrakı Serkurenalık Maruzatı) \\ Y.PRK.UM (Yıldız Perakende Evrakı Umumi) \\ Y.PRK.TKM (Yıldız Perakende Evrakı Tahrirat-ı Ecnebiye ve Mabeyn Mütercimliği) \\ Turkish Historical Society Archives \\ (Türk Tarih Kurumu Arşivi, TTK, Ankara) \\ Kazım Orbay Koleksiyonu \\ Centre des Archives diplomatique de Nantes (CADN) \\ 166PO/D20/13
}




\author{
The National Archives (Kew, London) \\ FO 195 \\ FO 78 \\ FO 371
}

\title{
Archives of the Turkish General Chief of Staff (Genelkurmay Askerî Tarih ve Stratejik Etüt Arşivi, ATASE) \\ Klasör 6 \\ Klasör 3215
}

\section{Politisches Archiv, Auswaertiges Amt (PA-AA, Berlin)}

Türkei 165, Bd. 37

Türkei 165, Bd. 42

Haus-, Hof-, und Staatsarchiv (HHStA, Vienna)

PA 38/366

PA $38 / 369$

PA 38/371

\section{Secondary sources}

Anscombe, Frederick F. The Ottoman Gulf: The Creation of Kuwait, Saudi Arabia and Qatar. New York: Columbia University Press, 1997.

Çetinsaya, Gökhan. The Ottoman Administration of Iraq, 1890-1908. London: Routledge, 2006.

Ceylan, Ebubekir. The Ottoman Origins of Modern Iraq: Political Reform, Modernization and Development in the Nineteenth Century Middle East. London: I.B. Tauris, 2011.

Enazy, Askar H. al-. The Creation of Saudi Arabia: Ibn Saud and British Imperial Policy. London: Routledge, 2010.

Halaçoğlu, Yusuf. "Midhat Paşa'nın Necid ve Havalisi ile İlgili Birkaç Lâyihası." Tarih Enstitüsü Dergisi 3 (1973): 149-176.

Kühn, Thomas. Empire, Islam, and Politics of Difference. Leiden: Brill, 2011.

Kurşun, Zekeriya. Necid ve Ahsa'da Osmanlı Hâkimiyeti: Vehhabi Hareketi ve Suudi Devleti'nin Ortaya Çıkışı. Ankara: Türk Tarih Kurumu Yayınları, 1998.

Rasheed, Madawi al-. Politics in an Arabian Oasis: The Rashidis of Saudi Arabia. London: I.B. Tauris, 1991.

—. "Durable and Non-Durable Dynasties: The Rashidis and Sa'udis in Central Arabia." British Journal of Middle Eastern Studies 19, no. 2 (1992): 144-158.

Rogan, Eugene L. Frontiers of the State in the Late Ottoman Empire: Transjordan, 1850-1921. Cambridge: Cambridge University Press, 1999.

Slot, B.J. Mubarak al-Sabah: Founder of Modern Kuwait, 1896-1915. London: Arabian Publishing, 2005.

Söylemezoğlu, Süleyman Şefik. Hicaz Seyahatnamesi. İstanbul: İz Yayıncılık, 2012.

Strohmeier, Martin. "Fakhri (Fahrettin) Pasha and the End of Ottoman Rule in Medina (1916-1919)." Turkish Historical Review 4, no. 2 (2013): 192-223.

Tahsin, Paşa. Yıldız Hatıraları. Edited by Ahmet Zeki İzgöer. İstanbul: İz Yayıncılık, 2015. 